\title{
Clinical implications of epithelial cell plasticity in cancer progression
}

\author{
Luis A. Aparicio ${ }^{\mathrm{a}}$, Moisés Blanco ${ }^{\mathrm{b}}$, Raquel Castosa ${ }^{\mathrm{b}}$, Ángel Concha ${ }^{\mathrm{c}}$, Manuel \\ Valladares $^{\mathrm{a}}$, Lourdes Calvo ${ }^{\mathrm{a}}$, Angélica Figueroa ${ }^{\mathrm{b}}$ \\ ${ }^{a}$ Servicio de Oncología Médica, INIBIC, CHUAC, Sergas, UDC, A Coruña, Spain \\ ${ }^{b}$ Grupo de Investigación Traslacional del Cáncer, Instituto de Investigación Biomédica de A Coruña (INIBIC), \\ Complexo Hospitalario Universitario de A Coruña (CHUAC), Sergas, Universidade da Coruña (UDC), As Xubias, \\ 15006, A Coruña, Spain \\ ${ }^{c}$ Servicio de Anatomía Patológica, INIBIC, CHUAC, Sergas, UDC, A Coruña, Spain
}

\begin{abstract}
In the last few years, the role of epithelial cell plasticity in cancer biology research has gained increasing attention. This concept refers to the ability of the epithelial cells to dynamically switch between different phenotypic cellular states. This programme is particularly relevant during the epithelial-to-mesenchymal transition (EMT) in cancer progression. During colonization, epithelial cells first activate the EMT programme to disseminate from a primary tumour to reach a distant tissue site. During this process, cells are transported into the circulation and are able to escape the immune system of the host. Then, a reverse process called mesenchymal-to-epithelial transition (MET) occurs on cells that settle in the distant organs. Although epithelial cell plasticity has an important impact on tumour biology, the clinical relevance of this concept remains to be recapitulated. In this review, we will update the current state of epithelial cell plasticity in cancer progression and its clinical implications for the design of therapeutic strategies, the acquisition of multidrug resistance, and future perspectives for the management of cancer patients.
\end{abstract}

\section{Keywords}

Cancer stem cells; Circulating tumour cells; Drug resistance; Epithelial plasticity; Medical perspective

\section{Abbreviations}

CTCs, circulating tumour cells; CSCs, cancer stem cells; DTCs, disseminating tumour cells; ECM, extracellular matrix; EMT, epithelial-to-mesenchymal transition; MET, mesenchymal-to-epithelial transition; SCLC, small cell lung cancer 


\section{Introduction}

The epithelial-to-mesenchymal transition (EMT) process was first described by developmental biologists as a highly conserved programme found in tissue remodelling during embryogenesis, histogenesis and organ morphogenesis. During this process, the embryonic epithelial cells suffer a phenotypic conversion to give rise to individual and migratory cells. During EMT, epithelial cell morphology is lost and the acquisition of motile characteristics results from the loss of apicobasal polarity and loss of cell-cell adhesion. The changes in cell polarity and cell-cell contacts are accompanied by actin cytoskeleton reorganization and by a disruption of cell adhesion to the extracellular matrix (ECM), allowing cells to penetrate into the ECM and migrate over distances, promoting metastasis. These newly formed mesenchymal phenotypes are characterized by an irregular, more extended and elongated shape and less strong cell-cell contacts compared to their epithelial counterparts, increasing their migratory ability [1], [2]. These phenotypic changes described were also observed in an early step during tumour progression and metastasis, elucidating the importance of the epithelial-to-mesenchymal transition in carcinomas [3]. Dr. Elizabeth Hay, who first described the EMT, illustrated the essential differences between movement in embryogenesis and tumorigenesis, defining the distinct EMT mechanism [4], [5], [6].

Given that most tumours are carcinomas, which arise from epithelial cells, EMT in cancer has been established as a crucial event. One of the hallmarks of EMT is the loss of expression of a key epithelial cell-cell adhesion molecule, E-cadherin. E-cadherin is the prototype and best characterized member of adherens junctions in epithelial cells and is considered to be a potent tumour suppressor. Although the decreased expression of E-cadherin is a characteristic of the EMT, this process is also characterized by the downregulation of other epithelial specification genes, such as components of tight junctions (ZO1), desmosomes (Desmoplakin), cytokeratins, and laminin. The loss of epithelial markers is accompanied by the induction of mesenchymal markers, such as N-Cadherin, cadherin-11 or vimentin, by the nuclear accumulation of $\beta$-catenin and by the reorganization of the cytoskeleton [7], [8]. This process is triggered in response to several extracellular signals, such as epidermal growth factor (EGF), transforming growth factor beta (TGF- $\beta$ ), and hepatocyte growth factor (HGF).

Given the crucial role of E-cadherin downregulation during EMT, different levels of E-cadherin regulation were extensively studied. It has been reported that at the transcriptional level, the activation of one or several transcription factors, referred to as repressors including the Snail/Slug family, Twist, ZEB1, and FOXC2, which are master molecular regulators of E-cadherin, also regulates the EMT. The loss of E-cadherin is driven by epigenetic control, by posttranscriptional regulators (such as microRNAs or RNA-binding proteins) [8], [9], [10], [11], or by posttranslational regulators (such as CK1 or Hakai) [12], [13], [14], [15], and these molecules regulate E-cadherin expression (Fig. 1). In addition to this level of regulation, the tumour microenvironment has also been shown to influence EMT by the modulation of cell-cell adhesion. For example, in the intestinal epithelium, EphB receptors are important regulators not only during embryogenesis but also during early stages of cancer progression. Indeed, EphB2 and EphB3 control cell positioning and ordered migration in the intestinal epithelium [16], [17]. Multiple Eph receptors and/or their ephrin ligands (Eph-ephrin) are expressed in both cancer cells and the tumour microenvironment, influencing tumour properties by enabling aberrant cell-cell communication within and between tumour compartments. Eph-ephrin can promote the establishment of cadherin-based cellcell adhesion and epithelial phenotype [18], [19], [20]. 


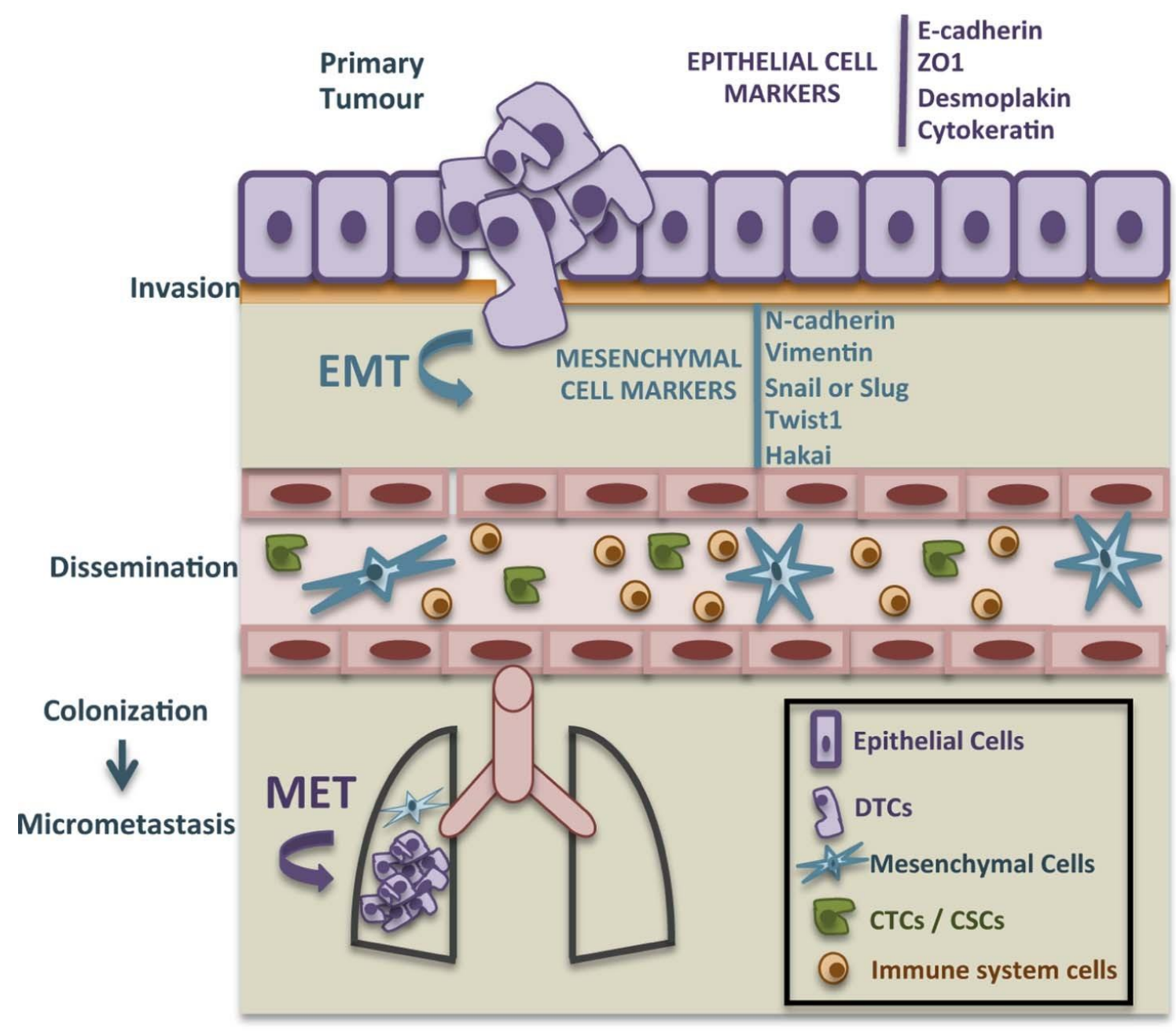

\section{EPITHELIAL PLASTICITY}

Fig. 1. Epithelial plasticity. The ability of epithelial cells to dynamically switch between different phenotypic cellular states is depicted. During EMT, epithelial cells expressing epithelial markers undergo phenotypic changes to give rise to the mesenchymal phenotype. The induction of EMT can also induce stem cell properties (CSCs). EMT also occurs during the dissemination of cells from the primary tumour (DCTs). Circulating tumour cells (CTCs) detach from the primary tumour and travel in the bloodstream, spreading from the original tumour to other locations, leading to cancer metastasis. All of these cells exist in the peripheral blood of cancer patients, and the detection of CTCs can help to determine the process of metastasis. The reverse process, mesenchymal-toepithelial transition (MET), occurs during metastatic colonization once malignant cells extravasate and find their niche in distant organs.

Since molecular biologists established the importance of E-cadherin as a hallmark of EMT, many studies reinforce that the loss of E-cadherin expression or function is associated with the transition from adenoma to carcinoma in clinical specimens. Pathologists also confirmed that loss of E-cadherin was associated with a lower differentiation grade and increased invasion and metastasis and is proposed as an indicator of poor prognosis [8], [21]. However, clinical evidence supporting the role of EMT in cancer progression is still open to discussion because the identification of cancer cells undergoing EMT in clinical specimens is very difficult to observe in primary tumours, making it reasonable for some pathologists to argue a concept that they have not clearly observed in their analysis of biopsies. The reverse process, known as mesenchymal-to-epithelial transition (MET), was also described to be 
necessary for metastatic colonization once malignant cells extravasate and find their niche in distant organs. Although this plasticity during EMT is considered to be the most striking manifestation of epithelial plasticity, the relative contribution of EMT to disease may be debatable because different degrees of epithelial plasticity have been observed. Cellular plasticity refers to the ability of cells to adopt an alternative cellular fate, differentiate into another cellular lineage (transdifferentiation), or dedifferentiate and revert to a less differentiated state of the same lineage. The induction of EMT can also induce stem cell properties [22]. Cancer stem cells (CSC) are a rare population within a tumour that has the ability to self-renew and seed a new tumour. CSCs can arise from either mutated normal tissue stem cells or from more differentiated cells that acquire stem cell properties, including self-renewal capacity and epithelial plasticity (EMT), due to genetic and epigenetic changes. CSCs can differentiate into all cell types of the heterogeneous tumour. In addition to cancer stem cells differentiating into transit-amplifying progenitor cells, the reverse process (dedifferentiation into CSCs) may also occur under certain conditions at various stages of cancer progression. Epithelial plasticity enables cancer cells to adapt to changes in the tumour (micro)environment. On the other hand, EMT also occurs during the dissemination of cells from the primary tumour. Circulating tumour cells (CTCs) are tumour cells that detach from the primary tumour and travel in the bloodstream, spreading from the original tumour to other locations and leading to cancer metastasis. These cells exist in the peripheral blood of cancer patients and the detection of CTCs can help to determine the process of metastasis. In contrast to other blood cells, the number of CTCs is very small in blood, which makes them difficult to detect. The advances in in vivo imaging techniques and in the characterization of EMT signatures in circulating tumour cells (CTCs) extracted from blood samples from patients supported that EMT occurs during dissemination from the primary tumour [23], [24], [25], [26]. Moreover, the reverse process, MET, was reported to be an important event in further metastasis when circulating tumour cells (CTCs) settle in distant organs and establish micrometastasis (Fig. 1). Therefore, epithelial plasticity can contribute to tumour heterogeneity, which describes the differences between tumours of the same type in different patients, and between cancer cells within a tumour. In addition, epithelial plasticity and heterogeneity in tumour biology also have an impact on the design of therapeutic strategies [27], given that one of the main risks in the appearance of tumour recurrence is associated with acquired multidrug resistance and the appearance of signs of EMT and stemness in the residual or relapsed tumour after chemotherapy. On the other hand, the prognostic value of the EMT-related genes or proteins was also evaluated (Table 1). Given the acquired clinical impact of epithelial plasticity in cancer progression, we will go into detail about the current state of this field, paying attention to the clinical implications to develop new clinical targets and to manage cancer patients. 
Table 1. Prognostic value of EMT related gene and protein expression in different tumours.

\begin{tabular}{|c|c|c|c|c|c|}
\hline Gene & Expression & Tumour & Prognostic & Hazard ratios & Ref. \\
\hline \multirow{4}{*}{$\begin{array}{l}\text { Beta- } \\
\text { catenin }\end{array}$} & Aberrant in tumour & Gastric cancer & Poor OS & 1.85 (95\% CI: $1.39-2.46)$ & {$[28]$} \\
\hline & Aberrant in tumour & $\begin{array}{l}\text { Oesophageal } \\
\text { carcinoma }\end{array}$ & Poor OS & 1.71 (95\% CI: 1.46-2.01) & [29] \\
\hline & $\begin{array}{l}\text { Increased in nucleus of } \\
\text { tumour cells }\end{array}$ & $\mathrm{CRC}$ & Poor DFS and OS & $\begin{array}{l}1.87 \text { (95\% CI: } 1.28-2.71) \text { and } 1.55 \\
\text { (95\% CI: } 1.12-2.14)\end{array}$ & {$[30]$} \\
\hline & Reduced in tumour & NSCLC & Poor OS & 1.91 (95\% CI: $1.60-2.28)$ & {$[31]$} \\
\hline Twist & $\begin{array}{l}\text { Aberrant, increased in } \\
\text { tumour }\end{array}$ & Several tumours & $\begin{array}{l}\text { Poor PFS/RFS/MFS/DFS/CFS } \\
\text { and poor OS }\end{array}$ & $\begin{array}{l}2.36 \text { (95\% CI: } 1.76-3.17) \text { and } 2.07 \\
(95 \% \text { CI: } 1.63-2.63)\end{array}$ & {$[32]$} \\
\hline Snail & $\begin{array}{l}\text { Aberrant, increased in } \\
\text { tumour }\end{array}$ & Several tumours & $\begin{array}{l}\text { Poor PFS/RFS/MFS/DFS/CFS } \\
\text { and poor OS }\end{array}$ & $\begin{array}{l}1.54 \text { (95\% CI: } 1.17-2.02) \text { and } 1.63 \\
\text { (95\% CI: } 1.33-1.99)\end{array}$ & {$[32]$} \\
\hline \multirow{9}{*}{$\begin{array}{l}\text { E- } \\
\text { cadherin }\end{array}$} & Reduced in tumour & NSCLC & Poor OS & 1.19 (95\% CI: $1.01-1.40)$ & {$[33]$} \\
\hline & Reduced in tumour & NSCLC & Poor DFS/PFS and poor OS & $\begin{array}{l}1.58 \text { (95\% CI: } 1.21-2.05) \text { and } 1.59 \\
\text { (95\% CI: } 1.39-1.80)\end{array}$ & {$[34]$} \\
\hline & Reduced in tumour & $\mathrm{CRC}$ & Poor OS in Asian patients & 2.86 (95\% CI: $2.13-3.7)$ & {$[35]$} \\
\hline & Reduced in tumour & $\begin{array}{l}\text { Oesophageal } \\
\text { cancer }\end{array}$ & Poor OS & 1.33 (95\% CI: 1.16-1.52) & [36] \\
\hline & Reduced in tumour & Gastric cancer & Poor OS & 1.62 (95\% CI: $1.34-1.96)$ & [37] \\
\hline & Reduced in tumour & Ovarian cancer & Poor OS & 2.10 (95\% CI: $1.13-3.06)$ & {$[38]$} \\
\hline & Aberrant in tumour & HNSCC & Poor PFS and poor OS & $\begin{array}{l}2.628 \text { (95\% CI: } 1.868-3.699) \text { and } \\
2.533 \text { (95\% CI: } 1.971-3.254)\end{array}$ & [39] \\
\hline & Reduced in tumour & PDAC & Poor OS & 1.80 (95\% CI: $1.33-2.42)$ & {$[40]$} \\
\hline & $\begin{array}{l}\text { Reduced or absent in } \\
\text { tumour }\end{array}$ & BIDC & Increase risk of all-cause mortality & 1.55 (95\% CI: $1.08-2.23)$ & {$[41]$} \\
\hline \multirow[t]{2}{*}{$\operatorname{miR}-200 \mathrm{c}$} & Increased in blood & Several tumours & Poor PFS and poor OS & $\begin{array}{l}2.26 \text { (95\% CI: } 1.66-3.08) \text { and } 3.07 \\
\text { (95\% CI: } 1.58-5.96)\end{array}$ & {$[42]$} \\
\hline & Decreased in tumour & Several tumours & Poor OS in stage I patients & 0.41 (95\% CI: $0.25-0.68)$ & [42] \\
\hline
\end{tabular}

NSCLC: non-small cell lung cancer; CRC: colorectal cancer; HNSCC: head and neck squamous cell carcinoma; PDAC: pancreatic ductal adenocarcinoma; BIDC: breast infiltrating ductal carcinoma; OS: overall survival; PFS: progression free survival; RFS: recurrence-free survival; MFS: metastasis-free survival; DFS: disease-free survival; CFS: cancer-free survival; CI: confidence interval; Ref.: references.

\section{Epithelial plasticity in cancer progression}

Metastasis is responsible for the majority of cancer-related deaths. However, the metastatic cascade is not an efficient process, as less than $0.01 \%$ of cells from a primary tumour enter the circulation and develop metastases [43]. In many solid tumours, carcinoma cells undergo the EMT process, allowing cells to disseminate and metastasize by the acquisition of invasive and stem cell-like characteristics of the epithelial cells [44]. A reverse process called mesenchymal-to-epithelial transition (MET) was proposed to endow the disseminated cells with the ability to establish micrometastases [45]. However, most of the studies in cancer biology that have reported the relevance of EMT in tumour progression were performed in vitro; therefore, the evidence supporting the epithelial and mesenchymal plasticity in vivo was highly questioned [46]. Moreover, the current technology used to determine the role of EMT during in vivo dissemination was mainly supported by the detection of the expression of epithelial markers of circulating tumour cells (CTCs), resulting in a questionable representation of metastases. Clinical observations from breast cancer showed the appearance of clinical metastases after years of the resection of a tumour that did not initially present clinical evidence of metastasis at the time of diagnosis; moreover, approximately $4-5 \%$ of the clinical metastases develop without knowledge of the primary tumour [47]. These observations give rise to the idea that the dissemination of metastasis may occur even before the 
formation of a detectable primary tumour. This possibility has significant clinical and biological implications.

Evidence supporting the epithelial and mesenchymal plasticity has been recently provided in vivo[48], [49], [50]. In two manuscripts, two additional regulators of epithelial plasticity were identified: transcription factor paired related homeobox 1 (PRRX1), whose expression correlated with invasive phenotypes, and TWIST1, an already established transcription factor regulator of EMT and metastasis [51], [52]. Both transcription factors PRRX1 and TWIST1 induce EMT to undergo further invasion, intravasation and extravasation. Moreover, the suppression of PRRX1 induced MET (in cells that underwent EMT), stem cell-like properties and proliferation. Indeed, it was demonstrated that PRRX1 expression is associated with EMT and invasion, but its expression must be lost at later stages due to metastatic colonization. On the other hand, primary tumours expressing high levels of TWIST1 protein no longer expressed TWIST1 in most of the matched lymph node metastases. Using transgenic mice, it was demonstrated that suppression of Twist 1 expression (which occurs as cells disseminate from the primary sites) was required for metastasis formation, but the induction of metastasis in these mice no longer expressed TWIST1 and an epithelial phenotype was observed, indicating that MET had taken place [48], [49]. Interestingly, the analyses of peripheral blood from these mice showed that Twistl induction increased the number of circulating tumour cells (CTCs) that express TWIST1. Importantly, the suppression of Twistl expression in these cells allowed for their proliferation in vivo, indicating that MET is crucial for metastatic outgrowth. Therefore, the induction of EMT by PRRX1 and/or TWIST1 promotes invasion, intravasation and extravasation. Moreover, the downregulation of these EMT regulators is crucial for metastatic outgrowth.

Pathologists have recognized that distant metastatic lesions mainly reproduce the histological pattern of the primary tumour; however, signs of the EMT process or markers associated with cells that have undergone EMT should not necessarily be present in metastases. Although the evidence of epithelial and mesenchymal plasticity has been shown in mice, cell plasticity was also studied in patients, thanks to in vivo imaging techniques and the analysis of CTCs taken from blood samples [23], [53]. Indeed, the presence of mesenchymal markers in circulating tumour cells and disseminated tumour cells predicts poor prognosis [54]. However, as previously mentioned, these results can be misinterpreted as the purification of CTCs based on the presence of epithelial markers in CTCs, such as the epithelial cell adhesion molecule EpcAM, leading to an underestimation of the amount of CTCs if they have already undergone a complete EMT [55].

Another important contribution underlying the involvement of EMT during in vivo tumour progression was reported by Rhim et al. [50]. In this paper, the authors proposed that pancreatic metastasis occurs earlier than previously anticipated. To clarify the early events of invasive behaviour, they developed a sensitive system that allowed them to tag and track pancreatic epithelial cells in a mouse model of pancreatic cancer to detect and isolate cells of pancreatic epithelial origin during tumour progression. This system allowed them not only to determine the in vivo EMT and dissemination kinetics but also to correlate the cell phenotype with the acquisition of invasive and tumour-initiating properties. They found that these tagged cells were invasive even before the malignancy could be detected by histological approaches. These mesenchymal cells expressed protein markers associated with EMT such as Slug, Snail and Zeb1. Moreover, the circulating pancreatic cells not only maintained the mesenchymal phenotype but also expressed cancer stem cell markers such as CD24 and CD44 [56], further supporting the previously reported association between EMT and stem cell properties [22]. Furthermore, it was demonstrated that inflammation enhances cancer progression in part by inducing EMT and dissemination. Indeed, they showed that the induction of pancreatitis increased the number of CTCs and EMT at the inflammatory foci; in contrast, the dissemination was abrogated by immunosuppressive treatment using dexamethasone.

All of these investigations have an important clinical impact for future therapeutic strategies against metastasis. Inducing differentiation and targeting EMT alone might provoke the activation of the proliferation of disseminated cells, resulting in counterproductive therapy. Therefore, it is suggested that it may be useful to combine this therapy with standard chemotherapy to stop cycling cells. Indeed, 
clinical trials that compare neoadjuvant antimetastasis and cytotoxic therapies prior to surgery should be considered immediately for all cancer patients.

\section{Epithelial plasticity and cancer stem cells}

The EMT process has also been linked to the generation of epithelial cells that exhibit stem-cell properties. The concept of cancer stem cells (CSC) is still controversial, and it seems to be more appropriate to use the term "cancer stem cell paradigm" to refer to the existence of a rare population within a tumour that has the potential to self-renew and is responsible for the establishment, growth and maintenance of a tumour, having a high capacity for therapy resistance, angiogenesis and metastasis [22], [57]. One of the hypotheses regarding the origin of cancer stem cells is based on the transformation of a subpopulation of normal cells, which turn into CSC through their cellular plasticity. On the other hand, in specific tissues, it has been described that cancer stem cells express many features of the stem cell compartment, suggesting that tumorigenesis is initiated by the transformation of the stem cell compartment. For example, in normal crypts of the intestine, a graded expression of the EphB2 receptor in colorectal cancer has been reported that identifies the tumour cell population that exhibits intestinal stem cell-like or differentiated-like phenotypes [58]. These data support the idea that the local microenvironment may also contribute to the CSC phenotype and tumour heterogeneity.

It was proposed that during the transition from the epithelial to the mesenchymal phenotype, EMT enhances the tumorigenesis or renewability of tumour cells; indeed, the CD $44^{+} / \mathrm{CD} 24^{-}$subpopulation of normal and cancerous breast epithelial cells was suggested to have stem cell properties and express higher levels of EMT transcription factors than CD44 $/ \mathrm{CD} 24^{+}$cells [22], [44]. Moreover, increased levels of several genes that activate the EMT process (such as TGF- $\beta$, Wnt, Notch, EGF, Oct4, Hedgehog, Nanog and TNF- $\alpha$ ) were detected in cells that exhibit stem cell properties. External stimuli can induce breast CSC generation through EMT [59], which also underlines the importance of EMT in the generation of CSC, as it was shown that CTCs that undergo EMT frequently express CSC markers [60]. This evidence was suggested in other malignancies, such as colorectal, hepatocellular or pancreatic carcinoma [22], [61], [62], [63], [64]. The concept linking the EMT process and the generation of CSC opens up the possibility of developing therapeutic strategies designed to inhibit the EMT programme or to control MET in cancer cells.

In addition, several transcription factors and posttranscriptional regulators were established to control the EMT process [2], [11]. Indeed, some have been linked to EMT and stem cell properties, such as Zeb1, which negatively regulates the expression of miR-200 family microRNA. miR-200 inhibits stemness through the suppression of polycomb protein Bmi-1 expression, which is necessary for efficient selfrenewing cell divisions [65], [66]. Several studies have shown that non-stem cells can dedifferentiate to stem-like cells spontaneously [67]. Later on, two transcription factors, Slug and Sox9, were identified to cooperate with the EMT to convert differentiated mammary epithelial cells into the mammary stem cell state [68]. Celià-Terrassa et al. reported the relationship between CSCs and EMT programmes in local invasiveness and distant metastasis. In this paper, they linked the properties of metastatic tumourinitiating cells to an epithelial phenotype, suggesting that while enabling the invasiveness of tumour cells, EMT opposes the self-renewal gene programme that drives their local and metastatic growth [69]. Transcription factors that induce EMT may regulate proteins in self-renewal, but several signalling pathways involved in self-renewal can influence EMT. The Wnt- $\beta$-catenin pathway is involved in the induction of EMT and the generation and maintenance of CSC in several cancers, such as breast, colon, and liver carcinomas. Indeed, Wnt- $\beta$-catenin signalling has been proposed to be a major therapeutic target for the eradication of CSCs. Nuclear $\beta$-catenin is detected during EMT in the invading front of colorectal carcinoma. Moreover, Wnt signalling regulates the turnover and activity of the transcription factor Snail in breast cancer and in normal hepatocyte regeneration, providing a link between the regulation of EMT and Wnt signalling programmes through Snail. Through its action in repressing E-Cadherin expression, Snail may contribute to the suppression of epithelial characteristics, reinforcing Wnt- $\beta$-catenin signalling [70], [71], [72], [73]. On the other hand, Twist has been linked to CSC properties unrelated to selfrenewal but related to the suppression of apoptosis by suppressing the pro-apoptotic effects of the Myc 
oncogene and by repressing p53-induced pro-apoptotic genes. Therefore, transcription factors such as Snail, Zeb1 or Twist were proposed to be good targets for the design of low-molecular-weight drugs for cancer therapy; however, the generation of drugs targeting these transcription factors has not been successful, as these proteins did not exhibit accessible catalytic domains for further studies by molecular docking. Another interesting perspective to approach this issue is by targeting the signalling pathways described to initiate EMT and maintain the cells in the stem cell state, such as TGF- $\beta$, EGF, FGFs, Wnt and Notch ligands [74]. The development of an important drug directed against these signalling pathways has been extensively studied. Therefore, it is plausible that the combination of different drugs targeting these signalling pathways will help cancer stem cells exit the stem cell state.

\section{Cellular plasticity of circulating tumour cells}

More than $90 \%$ of cancer deaths are a consequence of the progress of disseminated metastasis [75]. Because the detection of disseminating tumour cells (DTCs) is based on invasive procedures, in recent years, the potential utility of circulating tumour cells (CTCs) has emerged. CTCs are often detected in the peripheral blood of patients with metastasis, and their presence was shown to correlate with a worse clinical outcome in various cancer types [76]. For example, in metastatic breast cancer patients, CTCs isolated from blood were found to overexpress stem cell and epithelial-to-mesenchymal transition markers [77], [78], and a high expression level of Snail mRNA was detected in the blood of hepatocellular carcinoma patients with extra-metastasis [79]. Usually, the detection of CTCs is based on several procedures that distinguish them from the surrounding haematopoietic cells by several characteristics, including physical properties (size, density, electric charge, deformability) and biological properties (surface protein expression, viability and invasion capacity). Positive selection is usually carried out with antibodies against the epithelial cell adhesion molecule (EpCAM), and subsequent immunocytological detection of CTC is performed by using antibodies against cytokeratins (CK), the intermediate filaments of epithelial cells [80]. In the 1970s, the EpCAM molecule was identified as an epithelial cell adhesion molecule that was highly expressed in epithelial cancers and at lower levels in normal simple epithelia; even more importantly, EpCAM expression was absent in blood cells [81]. Among the current EpCAM-based technologies, the automated CellSearch ${ }^{\circledR}$ system (Veridex, Warren, NJ, USA) was approved by the Food and Drug Administration (FDA) for monitoring CTCs in metastatic breast, colon, and prostate cancers [82], [83]. Although this technology is being used for clinical applications, it has still not been shown to be able to drive therapeutic decisions, as the results obtained are based on the presence of EpCAM epithelial markers in CTCs, leading to the underestimation of the amount of CTCs if they have already undergone a complete EMT [55]. Indeed, an increasing body of evidence suggests that CTCs are highly heterogeneous [53], [84], [85], and several phenotypes can be detected: (1) epithelial tumour cells that express epithelial markers such as the EpCAM cell adhesion molecule; (2) epithelial-to-mesenchymal transition (EMT+) cells in which low levels of epithelial markers are expressed together with the up-regulation of mesenchymal markers; (3) CTCs with hybrid epithelial/mesenchymal tumour cells, as this phenotype was reported in patients with metastatic nonsmall-cell lung cancer and metastatic breast cancer, and a higher incidence of CTCs that express EMTrelated proteins, such as vimentin and TWIST1, is often accompanied by the presence of stem cell markers; (4) irreversible mesenchymal tumour cells, a subpopulation of circulating tumour stem cells that has undergone EMT and become fixed in the mesenchymal lineage, therefore preventing it from returning to the epithelial phenotype; and (5) circulating tumour stem cells whose stem cell-like immunophenotype is based on hallmarks such as $\mathrm{CD} 44^{+} / \mathrm{CD} 24^{-/ \text {low }}[86]$. Thus, circulating tumour stem cells and mesenchymal tumour cells are underestimated in cancer dissemination using this technology. Given that CSCs express transcription factors that induce EMT, such as TWIST, SNAIL, and SLUG [22], it is highly plausible that these cells have downregulated epithelial markers, such as EpCAM, and have upregulated numerous mesenchymal markers. Therefore, CTCs including epithelial tumour cells (using markers such as EpCAM, EGFR, HER2, or Muc1), mesenchymal tumour cells (using mesenchymal markers such as Ncadherin, O-cadherin, vimentin, and fibronectin) and circulating tumour stem cells (using CD26, CD44, CD133, CXCR4 markers) may co-exist in the peripheral blood. Although CellSearch is presently the only technology approved by the FDA, several trials have been reported concerning the evaluation of CTCs with mesenchymal features, for example, using the mRNA expression of EMT transcription factors. 
These systems overcome the discussed limitation of EpCAM enrichment. Moreover, recent publications underline the prognostic value of CTC in disease progression and treatment resistance in several types of cancer [53], [87], [88], [89], [90], [91]. Given that EMT increases cell migration and invasion and facilitates metastasis in multiple carcinoma types and that MET has a role in secondary tumour growth [92], it has been proposed that the isolation of CTCs can be used. It would be more reliable to use a combination of physical methods and negative selection containing epithelial and non-epithelial phenotypes, including circulating tumour stem cells and mesenchymal tumour cells derived from EMT. However, the isolation of CTCs by the combination of these procedures does not necessarily select tumour-derived cells, as they can be contaminated by the presence of stromal cells or normal blood vessel cells, stem cells, or other types of cells found in lower quantities in the circulation [93].

On the other hand, CTCs are continuously exposed to a hostile environment in the blood. Indeed, it is probable that only a few CTCs shed in the bloodstream can survive. Indeed, CTCs can be eliminated in blood by natural killer (NK) cells, monocytes/macrophages, and neutrophils; therefore, CTCs need to develop a phenotype that can protect them from the immune system and make them resistant to cellmediated cell death. Given that CTCs express EMT and CSC markers and that both are involved in the decreased sensitivity to cytotoxic immune effectors, one could expect that several of those markers could be responsible for the resistance to cell-mediated cell death. Indeed, it was demonstrated that Snailinduced EMT accelerates cancer metastasis not only through invasion but also through the induction of immunosuppression by inducing regulatory $\mathrm{T}$ cells. Moreover, although it was proven that Snailexpressing melanoma cells do not respond to immunotherapy, the in vivo injection of Snail-specific siRNA expressing tumour cells significantly inhibited tumour growth and metastasis followed by systemic immune responses and an increased number of tumour-infiltrating lymphocytes [94], [95]. Still, little is known about how tumour cells escape from the immune system of the host; therefore, the identification of immune-escape mechanisms as potential targets to disrupt the metastatic cascade in cancer is an attractive future perspective that needs to be further investigated.

\section{Cancer drug resistance and EMT}

EMT not only is an essential process for cellular plasticity in normal tissues during organ development and in malignant phenotypes during the invasion and stemming of cancer cells but also has been linked to resistance to chemotherapy. At present, several ongoing trials and compounds are being tested to therapeutically target epithelial plasticity-related genes (Table 2); however, therapeutic resistance mediated by EMT has been observed in several types of cancers. Several publications support that EMT and the induction of EMT genes are part of an adaptive response to therapeutic drugs by the acquisition of mesenchymal features for gain-of-function and resistance to cell death. Several EMT transcription repressors of E-cadherin, such as Snail/Twist and Zeb1, were reported to induce drug resistance [96], [97]. Increased levels of Zeb-1 and Twist and reduced levels of E-cadherin and other epithelial markers correspond to resistance to several drugs, such as 5-fluorouracil, gemcitabine or cisplatin [98]. In several tumour types, such as pancreatic or colorectal tumours, EMT biomarkers such as E-cadherin or vimentin can be used as predictors of the treatment outcome of EGFR inhibitors [99]. In head and neck squamous cell carcinoma and non-small cell lung carcinoma, the increased protein expression of vimentin combined with the loss of E-cadherin, claudin 4, and claudin 7 was associated with genfitinib resistance [100]. Moreover, studies of drug sensitivity in various cancer cells show that following the EMT process, cells were resistant to radiation [101], paclitaxel [102] and cisplatin [103], [104]. Changes in EMT markers were also observed to be associated with insensitivity to chemoradiotherapy in non-small cell lung cancer [105]. Another described example in which EMT is linked to the acquisition of stem-like activities and insensitivity to the EGFR-targeted agent erlotinib was described for lung, pancreatic, and head and neck cancer cells [106], [107]. Moreover, EMT markers act as determinants of insensitivity to genfitinib, an EGFR-tyrosine kinase. In lung adenocarcinoma cells, the activation of Notch-1 signalling enhances EMT in genfitinib-acquired resistance [108]. In HER-positive metastatic breast carcinoma, a rate of inherent resistance to trastuzumab (Herceptin) over $70 \%$ was observed. Several studies supported the contribution of specific EMT transcription factors involved in this resistance to trastuzumab. Indeed, SLUG/SNAIL2-positive basal/HER2+ cell lines exhibited an inherent 
resistance to trastuzumab, and the stem-related $\mathrm{CD} 44^{+} / \mathrm{CD} 24^{-/ \text {low }}$ mesenchymal phenotype was unresponsive to trastuzumab. When SLUG/SNAIL2-knockdown basal/HER2+ cell lines were injected into nude mice, a reduction in tumour growth and gain in sensitivity to trastuzumab were observed. These data support that these EMT transcription factors can enhance phenotypic plasticity, allowing basal/HER2+ breast cancer cells to dynamically respond to trastuzumab in stem cell-like states. The authors suggest that the determination of SLUG/SNAIL2 and a stem/CD44 ${ }^{+}$and CD24-/low cell-associated protein may impact the therapeutic strategy for HER2+ breast carcinomas [109]. As tumorigenic $\mathrm{CD} 44^{+} / \mathrm{CD} 24^{-/ \text {low }}$ cells may be resistant to chemotherapy and responsible for cancer relapse, it was demonstrated that the inhibition of EGFR/HER2 signalling through lapatinib treatment led to a decrease in the percentage of tumorigenic cancer cells and in the self-renewal of HER2-positive cancers [110]. Another important example was observed in small cell lung cancer (SCLC) resistance to chemotherapy. Crizotinib is a drug that inhibits Met and Alk kinases, which act in patients with Alk-positive non-small cell lung cancer. Crizotinib is also effective in tumours with Met amplification. EMT can be induced by growth factors such as hepatocyte growth factor (HGF), the natural ligand of Met tyrosine kinase receptor. Selection of the correct patient population for specific treatment has become increasingly relevant for the impact of these targeted drugs in patients' outcomes [111], [112], [113]. It was demonstrated that by using preclinical models, the activation of the Met pathway induces the EMT phenotype in SCLC cells and generates a mesenchymal population that is more tumorigenic and chemoresistant to crizotnib than the parental cells. Met-specific inhibition via the modulation of these mesenchymal biomarkers subsequently increases chemosensitivity in SCLC models. Moreover, the mesenchymal features and Met phosphorylation are predictive of poor survival in patients with SCLC and are upregulated in chemoresistant or relapsed tumours. The authors proposed that Met-mediated EMT leads to chemoresistance, and the inhibition of MET is able to reverse this chemoresistance. Therefore, it was proposed that the selection of patients according to mesenchymal biomarkers in combination with Met expression is a good alternative for selecting patients with SCLC for clinical trials of Met inhibitors plus chemotherapy [114]. On the other hand, it was also reported that gold nanoparticles inhibited ovarian tumour growth and metastasis in mice by reverting EMT. Recently, it was suggested that the gold nanoparticles can prevent cisplatin-induced acquired chemoresistance and stemness in ovarian cancer cells and sensitize them to cisplatin [115]. Therefore, new therapeutic strategies are emerging to overcome the acquired drug resistance.

Table 2. Selected ongoing clinical trials and compounds with targets potentially related to epithelial-mesenchymal plasticity.

\begin{tabular}{|c|c|c|c|c|}
\hline Compound & Target & Tumours & Clinical trials* & Phase \\
\hline \multirow[t]{2}{*}{ Tivantinib (ARQ 197) } & c-Met & $\begin{array}{l}\text { Locally advanced or metastatic non-small cell lung } \\
\text { cancer }\end{array}$ & $2010-022365-10$ & III \\
\hline & & Hepatocellular carcinoma & 2012-003308-10 & III \\
\hline $\begin{array}{l}\text { Trametinib } \\
\text { (GSK1120212) }\end{array}$ & $\mathrm{MEK} 1 / 2$ & BRAF mutant melanoma & $\begin{array}{l}2010-022838-85 \\
2012-001266-15 \\
2011-006088-23 \\
2011-006087-49\end{array}$ & III \\
\hline PD0325901 & MEK1/2 & $\begin{array}{l}\text { Metastatic colorectal cancer, non-small cell lung cancer, } \\
\text { pancreatic cancer }\end{array}$ & 2013-003299-10 & II \\
\hline MSC2156119J & c-Met & Hepatocellular carcinoma & 2013-002053-30 & $\mathrm{I} / \mathrm{II}$ \\
\hline PF-03446962 & ALK & $\begin{array}{l}\text { Relapsed or refractory advanced or metastatic urothelial } \\
\text { cancer }\end{array}$ & 2011-005983-12 & II \\
\hline \multirow{3}{*}{$\begin{array}{l}\text { Galunisertib } \\
\text { (LY2157299) }\end{array}$} & TGFBR1 & Advanced or metastatic unresectable pancreatic cancer & 2011-000211-64 & $\mathrm{Ib} / \mathrm{II}$ \\
\hline & & Glioblastoma & 2011-004418-40 & II \\
\hline & & Hepatocellular carcinoma & $2010-022338-10$ & II \\
\hline
\end{tabular}


Table 2. Selected ongoing clinical trials and compounds with targets potentially related to epithelial-mesenchymal plasticity.

\begin{tabular}{|c|c|c|c|c|}
\hline Compound & Target & Tumours & Clinical trials* & Phase \\
\hline \multirow[t]{4}{*}{ Linsitinib (OSI 906) } & \multirow[t]{4}{*}{ IGF-IR, IR } & Ewing sarcoma & $2012-000616-28$ & II \\
\hline & & Ovarian cancer & 2009-010319-34 & $\mathrm{I} / \mathrm{II}$ \\
\hline & & Hepatocellular carcinoma & 2010-018739-17 & II \\
\hline & & Non-small cell lung cancer & 2010-020916-12 & II \\
\hline \multirow[t]{2}{*}{ Nintedanib (BIBF1120) } & \multirow{2}{*}{$\begin{array}{l}\text { VEGFR1/2/3, } \\
\text { FGFR1/2/3, and } \\
\text { PDGFR-alpha/beta }\end{array}$} & Colorectal cancer refractory to standard therapies & $2012-000095-42$ & III \\
\hline & & $\begin{array}{l}\text { Stage IIIB/IV or recurrent non-small cell lung cancer } \\
\text { after failure of first line chemotherapy }\end{array}$ & $2007-004803-36$ & III \\
\hline \multirow[t]{2}{*}{ MEHD7945A } & \multirow[t]{2}{*}{ Dual EGFR/HER3 } & KRAS wild type metastatic colorectal cancer & 2011-005547-27 & II \\
\hline & & Squamous cell carcinoma of head and neck & 2011-005539-22 & II \\
\hline \multirow[t]{2}{*}{ Binimetinib (MEK162) } & \multirow[t]{2}{*}{ MEK1/2 } & Ovarian cancer & 2013-000277-72 & III \\
\hline & & $\begin{array}{l}\text { Metastatic or unresectable (NRAS or BRAF mutant) } \\
\text { melanoma }\end{array}$ & $\begin{array}{l}2013-001176-38 \\
2013-001176-38 \\
2012-003593-51\end{array}$ & III \\
\hline Encorafenib (LGX818) & BRAF & BRAF mutant melanoma & 2013-001176-38 & III \\
\hline $\begin{array}{l}\text { Rozrolimupab } \\
\text { (Sym004) }\end{array}$ & EGFR & $\begin{array}{l}\text { Anti-EGFR antibodies refractory metastatic colorectal } \\
\text { cancer }\end{array}$ & $2013-003829-29$ & II \\
\hline \multirow[t]{2}{*}{$\begin{array}{l}\text { Gedatolisib (PF- } \\
\text { 05212384) }\end{array}$} & \multirow{2}{*}{$\begin{array}{l}\mathrm{PI} 3 \mathrm{~K} / \mathrm{mTOR} \text { (PI3K- } \\
\text { alpha, PI3K-gamma, } \\
\text { and mTOR) }\end{array}$} & Metastatic colorectal cancer & $\begin{array}{l}2013-002096-18 \\
2013-002095-40\end{array}$ & II \\
\hline & & Endometrial cancer & 2011-003062-32 & II \\
\hline Neratinib (HKI-272) & Dual EGFR/HER2 & HER2 positive breast cancer & $\begin{array}{l}2012-004492-38 \\
2008-007345-31 \\
2008-005425-11 \\
2008-007803-10\end{array}$ & III \\
\hline Ganitumab (AMG 479) & IGF-IR & Metastatic pancreatic cancer & 2010-020398-18 & III \\
\hline Buparlisib (BKM120) & $\begin{array}{l}\text { Pan-PI3K (PI3K- } \\
\text { alpha, beta, gamma, } \\
\text { and delta) }\end{array}$ & Metastatic breast cancer & $\begin{array}{l}2011-005524-17 \\
2012-002571-34 \\
2011-005932-24\end{array}$ & III \\
\hline Encorafenib (LGX818) & BRAF & Unresectable or metastatic BRAF mutant melanoma & 2013-001176-38 & III \\
\hline BYL719 & PI3K-alfa & $\begin{array}{l}\text { Hormone receptor-positive HER2-negative breast } \\
\text { cancer }\end{array}$ & $2013-001862-41$ & II \\
\hline $\begin{array}{l}\text { Dabrafenib } \\
\text { (GSK2118436) }\end{array}$ & BRAF & BRAF mutant melanoma & $\begin{array}{l}2011-006087-49 \\
2012-001266-15 \\
2011-006088-23\end{array}$ & III \\
\hline $\begin{array}{l}\text { Onartuzumab } \\
\text { (MetMAb) }\end{array}$ & c-MET & Non-small cell lung cancer & $\begin{array}{l}2013-000868-29 \\
2011-002224-40\end{array}$ & III \\
\hline & & Gastro-oesophageal cancer & $2012-001402-23$ & III \\
\hline Capmatinib (INC280) & c-MET & $\begin{array}{l}\text { Locally advanced or metastatic BRAF mutant } \\
\text { melanoma }\end{array}$ & $\begin{array}{l}2012-004798-17 \\
2013-004552-38\end{array}$ & II \\
\hline EGF816 & EGFR & EGFR mutated non-small cell lung cancer & 2014-000726-37 & $\mathrm{Ib} / \mathrm{II}$ \\
\hline LY2875358 & c-MET & Metastatic non-small cell lung cancer & $\begin{array}{l}2012-005476-33 \\
2012-005477-31\end{array}$ & II \\
\hline AMG 337 & c-MET & Gastric and oesophageal cancer & $2013-001277-24$ & II \\
\hline Rilotumumab (AMG & HGF & Ovarian cancer & 2011-001112-53 & III \\
\hline 102) & & Gastro-oesophageal cancer & 2011-004923-11 & III \\
\hline $\begin{array}{l}\text { Ruxolitinib } \\
\text { (INCB018424) }\end{array}$ & JAK1/2 & Advanced or metastatic pancreatic cancer & $\begin{array}{l}2014-000293-20 \\
2014-000294-39\end{array}$ & III \\
\hline $\begin{array}{l}\text { Lucanix }{ }^{\mathrm{TM}} \\
\text { (Belagenpumatucel-L) }\end{array}$ & TGF- $\beta 2$ & Non-small cell lung cancer & 2007-005234-36 & III \\
\hline $\begin{array}{l}\text { Dacomitinib (PF- } \\
\text { 00299804) }\end{array}$ & $\begin{array}{l}\text { Pan-Erbb (EGFR, } \\
\text { HER2, and HER4) }\end{array}$ & Non-small cell lung cancer & $\begin{array}{l}2012-004977-23 \\
2010-022656-22\end{array}$ & III \\
\hline
\end{tabular}


Table 2. Selected ongoing clinical trials and compounds with targets potentially related to epithelial-mesenchymal plasticity.

\begin{tabular}{|c|c|c|c|c|}
\hline Compound & Target & Tumours & Clinical trials* & Phase \\
\hline \multirow[t]{3}{*}{ BGJ398 } & \multirow{3}{*}{$\begin{array}{l}\text { Pan-FGFR (FGFR1- } \\
\text { 4) }\end{array}$} & Recurrent resectable or unresectable glioblastoma & 2013-002200-13 & II \\
\hline & & Cholangiocarcinoma & 2013-005085-19 & II \\
\hline & & $\begin{array}{l}\text { Locally advanced or metastatic BRAF mutant } \\
\text { melanoma }\end{array}$ & $\begin{array}{l}2012-004798-17 \\
2013-004552-38\end{array}$ & II \\
\hline PF 03084014 & Gamma-secretase & Advanced triple negative breast cancer & 2014-002286-30 & II \\
\hline MK-0752 & Gamma-secretase & Metastatic pancreatic cancer & $2008-004829-42$ & II \\
\hline \multirow[t]{4}{*}{$\begin{array}{l}\text { Catumaxomab } \\
\text { (Removab }\end{array}$} & \multirow{4}{*}{$\begin{array}{l}\text { Ep-CAM [monoclonal } \\
\text { bispecific (also CD3- } \\
\text { specific) trifunctional } \\
\text { (also with effector cell } \\
\text { activation function) } \\
\text { antibody] }\end{array}$} & $\begin{array}{l}\text { Peritoneal carcinomatosis from gastric or colorectal } \\
\text { adenocarninomas }\end{array}$ & 2010-022810-26 & II \\
\hline & & $\begin{array}{l}\text { Gastro-oesophageal cancer with peritoneal } \\
\text { carcinomatosis }\end{array}$ & 2010-024111-13 & II \\
\hline & & $\begin{array}{l}\text { Gastric adenocarcinoma after neoadjuvant } \\
\text { chemotherapy and intended curative resection }\end{array}$ & 2006-002727-16 & II \\
\hline & & Malignant ascites & 2009-014076-22 & II \\
\hline \multirow[t]{4}{*}{ Cabozantinib (XL184) } & \multirow{4}{*}{$\begin{array}{l}\text { Multiple RTKs } \\
\text { (VEGFR2, c-Met, } \\
\text { RET, KIT, FLT1/3/4, } \\
\text { Tie2, and AXL) }\end{array}$} & $\begin{array}{l}\text { VEGFR inhibitors refractory metastatic renal cell } \\
\text { carcinoma }\end{array}$ & 2013-001010-14 & III \\
\hline & & Sorafenib refractory hepatocellular carcinoma & 2013-001001-91 & III \\
\hline & & $\begin{array}{l}\text { Previously treated symptomatic castration-resistant } \\
\text { prostate cancer }\end{array}$ & 2012-001426-99 & III \\
\hline & & Metastatic castration-resistant prostate cancer & 2012-001834-33 & III \\
\hline
\end{tabular}

When possible, only phase III studies were indicated; otherwise, selected phase II studies were stated. The information was extracted from EU Clinical Trials Register (https://www.clinicaltrialsregister.eu). RTKs: Receptors Tyrosine Kinase.

* EUdraCT Number.

\section{Conclusions}

In sum, it is clear that new therapeutic strategies need to be considered based on cellular plasticity. Strict action against cancer stem cells is unlikely to be a sufficient strategy given that stem cells can be generated from the remaining differentiated tumour cells. The combination of classical chemotherapy with anti-cancer stem cell drugs to attack non-stem and cancer stem cells within the tumour is a better option. Many efforts from the industry have focussed on the inhibition of metastasis by preventing the delamination of the primary tumour through the inhibition of EMT. Although this strategy is promising in specific types of cancer (as described in a mouse model of ovarian carcinoma) [116], the reported role of the epithelial plasticity during metastatic colonization opens up the possibility of favouring the formation of secondary tumours by the reversal of the mesenchymal phenotype to the epithelial phenotype through MET [48], [49] rather than preventing metastasis. This point is crucial in certain types of cancer, such as pancreatic or breast carcinomas, in which EMT occurs as a very early event in tumorigenesis and cancer cells have already disseminated before the tumour has been diagnosed [50], [117]. A promising strategy to determine the best therapeutic decision in every cancer patient is the generation of individualized mouse xenografts, named the "avatar mouse model." The avatar mouse model carries cancer cells from individual human patients and allows personalized cancer treatment in real time [118], [119] by selecting the most effective treatment for the patient. Finally, an increasing body of evidence notes the relevance of the immune system in the regulation of cancer progression, facilitating survival in late stages of tumour progression. However, little is known about the mechanism involved in the tumour cells' escape from the immune system and the molecular markers involved in epithelial plasticity. New targets for therapeutic intervention to avoid immune system attack need to be elucidated. 


\section{Authors' contributions}

AF participated in the design of the review and drafted the manuscript. All authors discussed and contributed to the improvement of the manuscript. All authors read and approved the final version of the manuscript.

\section{Conflict of interest}

The authors declare that they have no competing interests.

\section{Acknowledgments}

This work was supported by Plan Estatal I + D + I 2013-2016 (PI13/00250), co-funded by the ISCIII Fondo Europeo de Desarrollo Regional (FEDER) "A Way of Making Europe" from Secretaría Xeral I + D + I (10CSA916023PR) and from Consellería de Sanidade (PS09/24), both from Xunta de Galicia. R.C. was the recipient of a grant from Secretaria Xeral I + D + I (10CSA916023PR), Xunta de Galicia. A.F. was supported by Secretaria Xeral I + D + I (IPP.08-07), from Xunta de Galicia

\section{References}

[1] J. Lim, J.P. Thiery. Epithelial-mesenchymal transitions: insights from development. Development, 139 (2012), pp. 3471-3486

[2] M.A. Nieto, A. Cano. The epithelial-mesenchymal transition under control: global programs to regulate epithelial plasticity. Semin. Cancer Biol, 22 (2012), pp. 361-368

[3] J.P. Thiery. Epithelial-mesenchymal transitions in tumour progression. Nat. Rev. Cancer, 2 (2002), pp. 442-454

[4] R.L. Trelstad, E.D. Hay, J.D. Revel. Cell contact during early morphogenesis in the chick embryo. Dev. Biol, 16 (1967), pp. 78-106

[5] E.D. Hay. Organization and Fine Structure of Epithelium and Mesenchyme in the Developing Chickembryo. Baltimore, MD (1968)

[6] E.D. Hay. The mesenchymal cell, its role in the embryo, and the remarkable signaling mechanisms that create it. Dev. Dyn, 233 (2005), pp. 706-720

[7] M.A. Nieto. Epithelial plasticity: a common theme in embryonic and cancer cells. Science, 342 (2013), p. 1234850

[8] K. Vleminckx, L. Vakaet, M. Mareel, W. Fiers, F. van Roy. Genetic manipulation of E-cadherin expression by epithelial tumor cells reveals an invasion suppressor role. Cell, 66 (1991), pp. 107-119

[9] S.M. Park, A.B. Gaur, E. Lengyel, M.E. Peter. The miR-200 family determines the epithelial phenotype of cancer cells by targeting the E-cadherin repressors ZEB1 and ZEB2. Genes Dev, 22 (2008), pp. 894-907

[10] V. Abella, M. Valladares, T. Rodriguez, M. Haz, M. Blanco, N. Tarrío, et al. miR-203 regulates cell proliferation through its influence on Hakai expression. PLoS ONE, 7 (2012), p. e52568

[11] L.A. Aparicio, V. Abella, M. Valladares, A. Figueroa. Posttranscriptional regulation by RNAbinding proteins during epithelial-to-mesenchymal transition. Cell. Mol. Life Sci, 70 (2013), pp. 4463-4477

[12] L.A. Aparicio, M. Valladares, M. Blanco, G. Alonso, A. Figueroa. Biological influence of Hakai in cancer: a 10-year review. Cancer Metastasis Rev, 31 (2012), pp. 375-386

[13] T. Rodríguez-Rigueiro, M. Valladares-Ayerbes, M. Haz-Conde, L.A. Aparicio, A. Figueroa. Hakai reduces cell-substratum adhesion and increases epithelial cell invasión. BMC Cancer, 11 (2011), p. 474

[14] S. Dupre-Crochet, A. Figueroa, C. Hogan, E.C. Ferber, C.U. Bialucha, J. Adams, et al. Casein kinase 1 is a novel negative regulator of E-cadherin-based cell-cell contacts. Mol. Cell. Biol, 27 (2007), pp. 3804-3816

[15] Y. Fujita, G. Krause, M. Scheffner, D. Zechner, H. Leddy, J. Behrens, et al. Hakai, a c-Cbl-like protein, ubiquitinates and induces endocytosis of the E-cadherin complex. Nat. Cell Biol, 4 (2002), pp. 222-231

[16] E. Batlle, J.T. Henderson, H. Beghtel, M.M. van den Born, E. Sancho, G. Huls, et al .Betacatenin and TCF mediate cell positioning in the intestinal epithelium by controlling the expression of EphB/ephrinB. Cell, 111 (2002), pp. 251-263 
[17] E. Batlle, J. Bacani, H. Begthel, S. Jonkheer, S. Jonkeer, A. Gregorieff, et al. EphB receptor activity suppresses colorectal cancer progression. Nature, 435 (2005), pp. 1126-1130

[18] K. Miura, J.M. Nam, C. Kojima, N. Mochizuki, H. Sabe. EphA2 engages Git1 to suppress Arf6 activity modulating epithelial cell-cell contacts. Mol. Biol. Cell, 20 (2009), pp. 1949-1959

[19] T. Watanabe, Y. Sato, D. Saito, R. Tadokoro, Y. Takahashi. EphrinB2 coordinates the formation of a morphological boundary and cell epithelialization during somite segmentation. Proc. Natl. Acad. Sci. U.S.A., 106 (2009), pp. 7467-7472

[20] E.B. Pasquale. Eph receptors and ephrins in cancer: bidirectional signalling and beyond. Nat. Rev. Cancer, 10 (2010), pp. 165-180

[21] M. Takeichi. Cadherins in cancer: implications for invasion and metastasis. Curr. Opin. Cell Biol, 5 (1993), pp. 806-811

[22] S.A. Mani, W. Guo, M.J. Liao, E.N. Eaton, A. Ayyanan, A.Y. Zhou, et al. The epithelialmesenchymal transition generates cells with properties of stem cells. Cell, 133 (2008), pp. 704715

[23] D. Entenberg, D. Kedrin, J. Wyckoff, E. Sahai, J. Condeelis, J.E. Segall. Imaging tumor cell movement in vivo. Curr. Protoc. Cell Biol, 58 (2013), pp. 19.7.1-19.7.19

[24] M. Valladares-Ayerbes, M. Reboredo, V. Medina-Villaamil, P. Iglesias-Díaz, M.J. LorenzoPatiño, M. Haz, et al. Circulating miR-200c as a diagnostic and prognostic biomarker for gastric cancer. J. Transl. Med, 10 (2012), p. 186

[25] M. Valladares-Ayerbes, M. Blanco-Calvo, M. Reboredo, M.J. Lorenzo-Patiño, P. Iglesias-Díaz, M. Haz, et al. Evaluation of the adenocarcinoma-associated gene AGR2 and the intestinal stem cell marker LGR5 as biomarkers in colorectal cancer. Int. J. Mol. Sci, 13 (2012), pp. 4367-4387

[26] N. Bednarz-Knoll, C. Alix-Panabières, K. Pantel. Plasticity of disseminating cancer cells in patients with epithelial malignancies. Cancer Metastasis Rev, 31 (2012), pp. 673-687

[27] N.D. Marjanovic, R.A. Weinberg, C.L. Chaffer. Cell plasticity and heterogeneity in cancer. Clin. Chem, 59 (2013), pp. 168-179

[28] L.F. Li, Z.J. Wei, H. Sun, B. Jiang. Abnormal $\beta$-catenin immunohistochemical expression as a prognostic factor in gastric cancer: a meta-analysis. World J. Gastroenterol, 20 (2014), pp. 12313-12321

[29] R. Zeng, L. Duan, Y.K. Kong, X.L. Wu, Y. Wang, G. Xin, et al. Prognostic significance of beta-catenin expression in patients with esophageal carcinoma: a meta-analysis. Asian Pac. J. Cancer Prev, 15 (2014), pp. 6103-6108

[30] Z. Chen, X. He, M. Jia, Y. Liu, D. Qu, D. Wu, et al. $\beta$-catenin overexpression in the nucleus predicts progress disease and unfavourable survival in colorectal cancer: a meta-analysis. PLoS ONE, 8 (2013), p. e63854

[31] X.D. Mei, H. Su, J. Song, L. Dong. Prognostic significance of $\beta$-catenin expression in patients with non-small cell lung cancer: a meta-analysis. Biosci. Trends, 7 (2013), pp. 42-49

[32] P. Zhang, P. Hu, H. Shen, J. Yu, Q. Liu, J. Du. Prognostic role of Twist or Snail in various carcinomas: a systematic review and meta-analysis. Eur. J. Clin. Invest, 44 (2014), pp. 10721094.

[33] B. Yan, W. Zhang, L.Y. Jiang, W.X. Qin, X. WangReduced E-Cadherin expression is a prognostic biomarker of non-small cell lung cancer: a meta-analysis based on 2395 subjects. Int. J. Clin. Exp. Med, 7 (2014), pp. 4352-4356

[34] Y.L. Yang, M.W. Chen, L. Xian. Prognostic and clinicopathological significance of downregulated E-cadherin expression in patients with non-small cell lung cancer (NSCLC): a meta-analysis. PLoS ONE, 9 (2014), p. e99763

[35] X. He, Z. Chen, M. Jia, X. Zhao. Downregulated E-cadherin expression indicates worse prognosis in Asian patients with colorectal cancer: evidence from meta-analysis. PLoS ONE, 8 (2013), p. e70858

[36] X.L. Xu, Z.Q. Ling, S.Z. Chen, B. Li, W.H. Ji, W.M. Mao. The impact of E-cadherin expression on the prognosis of esophageal cancer: a meta-analysis. Dis. Esophagus, 27 (2014), pp. $79-86$

[37] X. Xing, Y.B. Tang, G. Yuan, Y. Wang, J. Wang, Y. Yang, et al. The prognostic value of Ecadherin in gastric cancer: a meta-analysis. Int. J. Cancer, 132 (2013), pp. 2589-2596

[38] H.L. Peng, L. He, X. Zhao. Association of reduced immunohistochemical expression of Ecadherin with a poor ovarian cancer prognosis - results of a meta-analysis. Asian Pac. J. Cancer Prev, 13 (2012), pp. 2003-2007

[39] Z. Zhao, J. Ge, Y. Sun, L. Tian, J. Lu, M. Liu, et al. Is E-cadherin immunoexpression a prognostic factor for head and neck squamous cell carcinoma (HNSCC)? A systematic review and meta-analysis. Oral Oncol, 48 (2012), pp. 761-767 
[40] N.B. Jamieson, C.R. Carter, C.J. McKay, K.A. Oien. Tissue biomarkers for prognosis in pancreatic ductal adenocarcinoma: a systematic review and meta-analysis. Clin. Cancer Res, 17 (2011), pp. 3316-3331

[41] B.E. Gould Rothberg, M.B. Bracken. E-cadherin immunohistochemical expression as a prognostic factor in infiltrating ductal carcinoma of the breast: a systematic review and metaanalysis. Breast Cancer Res. Treat, 100 (2006), pp. 139-148

[42] Y. Shao, Y. Geng, W. Gu, J. Huang, H. Pei, J. Jiang. Prognostic role of tissue and circulating microRNA-200c in malignant tumors: a systematic review and meta-analysis. Cell. Physiol. Biochem, 35 (2015), pp. 1188-1200

[43] P.B. Gupta, S. Mani, J. Yang, K. Hartwell, R.A. Weinberg. The evolving portrait of cancer metastasis. Cold Spring Harb. Symp. Quant. Biol, 70 (2005), pp. 291-297.

[44] K. Polyak, R.A. Weinberg. Transitions between epithelial and mesenchymal states: acquisition of malignant and stem cell traits. Nat. Rev. Cancer, 9 (2009), pp. 265-273

[45] R.L. Bitting, D. Schaeffer, J.A. Somarelli, M.A. Garcia-Blanco, A.J. Armstrong. The role of epithelial plasticity in prostate cancer dissemination and treatment resistance. Cancer Metastasis Rev, 33 (2014), pp. 441-468

[46] H. Ledford. Cancer theory faces doubts. Nature, 472 (2011), p. 273

[47] F.A. Greco, J.D. Hainsworth. Introduction: unknown primary cancer. Semin. Oncol, 36 (2009), pp. 6-7

[48] O.H. Ocaña, R. Córcoles, A. Fabra, G. Moreno-Bueno, H. Acloque, S. Vega, et al. Metastatic colonization requires the repression of the epithelial-mesenchymal transition inducer Prrx1. Cancer Cell, 22 (2012), pp. 709-724

[49] J.H. Tsai, J.L. Donaher, D.A. Murphy, S. Chau, J. Yang. Spatiotemporal regulation of epithelial-mesenchymal transition is essential for squamous cell carcinoma metastasis. Cancer Cell, 22 (2012), pp. 725-736

[50] A.D. Rhim, E.T. Mirek, N.M. Aiello, A. Maitra, J.M. Bailey, F. McAllister, et al. EMT and dissemination precede pancreatic tumor formation. Cell, 148 (2012), pp. 349-361

[51] J. Yang, S.A. Mani, J.L. Donaher, S. Ramaswamy, R.A. Itzykson, C. Come, et al. Twist, a master regulator of morphogenesis, plays an essential role in tumor metastasis. Cell, 117 (2004), pp. 927-939

[52] Y. Kang, J. Massagué. Epithelial-mesenchymal transitions: twist in development and metastasis. Cell, 118 (2004), pp. 277-279

[53] M. Yu, A. Bardia, B.S. Wittner, S.L. Stott, M.E. Smas, D.T. Ting, et al. Circulating breast tumor cells exhibit dynamic changes in epithelial and mesenchymal composition. Science, 339 (2013), pp. 580-584

[54] Gradilone, C. Raimondi, C. Nicolazzo, A. Petracca, O. Gandini, B. Vincenzi, et al. Circulating tumour cells lacking cytokeratin in breast cancer: the importance of being mesenchymal. J. Cell. Mol. Med, 15 (2011), pp. 1066-1070

[55] J. Kaiser. Medicine. Cancer's circulation problem. Science, 327 (2010), pp. 1072-1074

[56] C. Li, D.G. Heidt, P. Dalerba, C.F. Burant, L. Zhang, V. Adsay, et al .Identification of pancreatic cancer stem cells. Cancer Res, 67 (2007), pp. 1030-1037

[57] D.R. Pattabiraman, R.A. Weinberg. Tackling the cancer stem cells - what challenges do they pose?. Nat. Rev. Drug Discov, 13 (2014), pp. 497-512.

[58] Merlos-Suárez, F.M. Barriga, P. Jung, M. Iglesias, M.V. Céspedes, D. Rossell, et al. The intestinal stem cell signature identifies colorectal cancer stem cells and predicts disease relapse. Cell Stem Cell, 8 (2011), pp. 511-524

[59] M. Santisteban, J.M. Reiman, M.K. Asiedu, M.D. Behrens, A. Nassar, K.R. Kalli, et al .Immune-induced epithelial to mesenchymal transition in vivo generates breast cancer stem cells. Cancer Res, 69 (2009), pp. 2887-2895

[60] B.T. Hennessy, A.M. Gonzalez-Angulo, K. Stemke-Hale, M.Z. Gilcrease, S. Krishnamurthy, J.S. Lee, et al. Characterization of a naturally occurring breast cancer subset enriched in epithelial-to-mesenchymal transition and stem cell characteristics. Cancer Res, 69 (2009), pp. 4116-4124

[61] T. Brabletz, F. Hlubek, S. Spaderna, O. Schmalhofer, E. Hiendlmeyer, A. Jung, et al. Invasion and metastasis in colorectal cancer: epithelial-mesenchymal transition, mesenchymal-epithelial transition, stem cells and beta-catenin. Cells Tissues Organs, 179 (2005), pp. 56-65

[62] R.F. Niu, L. Zhang, G.M. Xi, X.Y. Wei, Y. Yang, Y.R. Shi, et al. Up-regulation of Twist induces angiogenesis and correlates with metastasis in hepatocellular carcinoma. J. Exp. Clin. Cancer Res, 26 (2007), pp. 385-394

[63] A.P. Morel, M. Lièvre, C. Thomas, G. Hinkal, S. Ansieau, A. Puisieux. Generation of breast cancer stem cells through epithelial-mesenchymal transition. PLoS ONE, 3 (2008), p. e2888 
[64] Z. Wang, Y. Li, D. Kong, S. Banerjee, A. Ahmad, A.S. Azmi, et al. Acquisition of epithelialmesenchymal transition phenotype of gemcitabine-resistant pancreatic cancer cells is linked with activation of the notch signaling pathway. Cancer Res, 69 (2009), pp. 2400-2407

[65] U. Burk, J. Schubert, U. Wellner, O. Schmalhofer, E. Vincan, S. Spaderna, et al. A reciprocal repression between ZEB1 and members of the miR-200 family promotes EMT and invasion in cancer cells. EMBO Rep, 9 (2008), pp. 582-589

[66] U. Wellner, J. Schubert, U.C. Burk, O. Schmalhofer, F. Zhu, A. Sonntag, et al. The EMTactivator ZEB1 promotes tumorigenicity by repressing stemness-inhibiting microRNAs. Nat. Cell Biol, 11 (2009), pp. 1487-1495

[67] C.L. Chaffer, I. Brueckmann, C. Scheel, A.J. Kaestli, P.A. Wiggins, L.O. Rodrigues, et al. Normal and neoplastic nonstem cells can spontaneously convert to a stem-like state. Proc. Natl. Acad. Sci. U.S.A., 108 (2011), pp. 7950-7955

[68] W. Guo, Z. Keckesova, J.L. Donaher, T. Shibue, V. Tischler, F. Reinhardt, et al. Slug and Sox9 cooperatively determine the mammary stem cell state. Cell, 148 (2012), pp. 1015-1028

[69] T. Celià-Terrassa, O. Meca-Cortés, F. Mateo, A.M. de Paz, N. Rubio, A. Arnal-Estapé, et al. Epithelial-mesenchymal transition can suppress major attributes of human epithelial tumorinitiating cells. J. Clin. Invest, 122 (2012), pp. 1849-1868

[70] C. Scheel, R.A. Weinberg. Cancer stem cells and epithelial-mesenchymal transition: concepts and molecular links. Semin. Cancer Biol, 22 (2012), pp. 396-403

[71] C. Zhao, J. Blum, A. Chen, H.Y. Kwon, S.H. Jung, J.M. Cook, et al. Loss of beta-catenin impairs the renewal of normal and CML stem cells in vivo. Cancer Cell, 12 (2007), pp. 528-541

[72] F. Takahashi-Yanaga, M. Kahn. Targeting Wnt signaling: can we safely eradicate cancer stem cells?. Clin. Cancer Res, 16 (2010), pp. 3153-3162

[73] P. Wend, J.D. Holland, U. Ziebold, W. Birchmeier. Wht signaling in stem and cancer stem cells. Semin. Cell Dev. Biol, 21 (2010), pp. 855-863

[74] P.B. Gupta, T.T. Onder, G. Jiang, K. Tao, C. Kuperwasser, R.A. Weinberg, et al. Identification of selective inhibitors of cancer stem cells by high-throughput screening. Cell, 138 (2009), pp. 645-659

[75] P. Mehlen, A. Puisieux. Metastasis: a question of life or death. Nat. Rev. Cancer, 6 (2006), pp. $449-458$

[76] S.J. Cohen, C.J. Punt, N. Iannotti, B.H. Saidman, K.D. Sabbath, N.Y. Gabrail, et al. Prognostic significance of circulating tumor cells in patients with metastatic colorectal cancer. Ann. Oncol, 20 (2009), pp. 1223-1229

[77] B. Aktas, M. Tewes, T. Fehm, S. Hauch, R. Kimmig, S. Kasimir-Bauer. Stem cell and epithelial-mesenchymal transition markers are frequently overexpressed in circulating tumor cells of metastatic breast cancer patients. Breast Cancer Res, 11 (2009), p. R46

[78] G. Kallergi, M.A. Papadaki, E. Politaki, D. Mavroudis, V. Georgoulias, S. Agelaki. Epithelial to mesenchymal transition markers expressed in circulating tumour cells of early and metastatic breast cancer patients. Breast Cancer Res, 13 (2011), p. R59

[79] A.L. Min, J.Y. Choi, H.Y. Woo, J.D. Kim, J.H. Kwon, S.H. Bae, et al. High expression of Snail mRNA in blood from hepatocellular carcinoma patients with extra-hepatic metastasis. Clin. Exp. Metastasis, 26 (2009), pp. 759-767

[80] K. Pantel, R.H. Brakenhoff, B. Brandt. Detection, clinical relevance and specific biological properties of disseminating tumour cells. Nat. Rev. Cancer, 8 (2008), pp. 329-340

[81] C. Patriarca, R.M. Macchi, A.K. Marschner, H. Mellstedt. Epithelial cell adhesion molecule expression (CD326) in cancer: a short review. Cancer Treat. Rev, 38 (2012), pp. 68-75

[82] S.J. Cohen, C.J. Punt, N. Iannotti, B.H. Saidman, K.D. Sabbath, N.Y. Gabrail, et al. Relationship of circulating tumor cells to tumor response, progression-free survival, and overall survival in patients with metastatic colorectal cancer. J. Clin. Oncol, 26 (2008), pp. 3213-3221

[83] J.S. de Bono, H.I. Scher, R.B. Montgomery, C. Parker, M.C. Miller, H. Tissing, et al .Circulating tumor cells predict survival benefit from treatment in metastatic castration-resistant prostate cancer. Clin. Cancer Res, 14 (2008), pp. 6302-6309

[84] G. Barrière, M. Tartary, M. Rigaud. Epithelial mesenchymal transition: a new insight into the detection of circulating tumor cells. ISRN Oncol, 2012 (2012), p. 382010

[85] L.M. Millner, M.W. Linder, R. Valdes. Circulating tumor cells: a review of present methods and the need to identify heterogeneous phenotypes. Ann. Clin. Lab. Sci, 43 (2013), pp. 295-304

[86] P.K. Grover, A.G. Cummins, T.J. Price, I.C. Roberts-Thomson, J.E. Hardingham. Circulating tumour cells: the evolving concept and the inadequacy of their enrichment by EpCAM-based methodology for basic and clinical cancer research. Ann. Oncol, 25 (2014), pp. 1506-1516

[87] M. Mego, S.A. Mani, B.N. Lee, C. Li, K.W. Evans, E.N. Cohen, et al. Expression of epithelialmesenchymal transition-inducing transcription factors in primary breast cancer: the effect of neoadjuvant therapy. Int. J. Cancer, 130 (2012), pp. 808-816 
[88] Giordano, H. Gao, S. Anfossi, E. Cohen, M. Mego, B.N. Lee, et al. Epithelial-mesenchymal transition and stem cell markers in patients with HER2-positive metastatic breast cancer. Mol. Cancer Ther, 11 (2012), pp. 2526-2534

[89] M. Mego, H. Gao, B.N. Lee, E.N. Cohen, S. Tin, A. Giordano, et al. Prognostic value of EMTcirculating tumor cells in metastatic breast cancer patients undergoing high-dose chemotherapy with autologous hematopoietic stem cell transplantation. J. Cancer, 3 (2012), pp. 369-380

[90] M.A. Watson, L.R. Ylagan, K.M. Trinkaus, W.E. Gillanders, M.J. Naughton, K.N. Weilbaecher, et al. Isolation and molecular profiling of bone marrow micrometastases identifies TWIST1 as a marker of early tumor relapse in breast cancer patients. Clin. Cancer Res, 13 (2007), pp. 5001-5009

[91] S. Antolín, L. Calvo, M. Blanco-Calvo, M.P. Santiago, M.J. Lorenzo-Patiño, M. Haz-Conde, et al. Circulating miR-200c and miR-141 and outcomes in patients with breast cancer. BMC Cancer, 15 (2015), p. 297

[92] C.L. Chaffer, J.P. Brennan, J.L. Slavin, T. Blick, E.W. Thompson, E.D. Williams. Mesenchymal-to-epithelial transition facilitates bladder cancer metastasis: role of fibroblast growth factor receptor-2. Cancer Res, 66 (2006), pp. 11271-11278

[93] M.G. Kolonin, K.W. Evans, S.A. Mani, R.H. Gomer. Alternative origins of stroma in normal organs and disease. Stem Cell Res, 8 (2012), pp. 312-323

[94] M.Z. Noman, Y. Messai, T. Carré, I. Akalay, M. Méron, B. Janji, et al. Microenvironmental hypoxia orchestrating the cell stroma cross talk, tumor progression and antitumor response. Crit. Rev. Immunol, 31 (2011), pp. 357-377

[95] C. Kudo-Saito, H. Shirako, T. Takeuchi, Y. Kawakami. Cancer metastasis is accelerated through immunosuppression during Snail-induced EMT of cancer cells. Cancer Cell, 15 (2009), pp. 195-206

[96] M.A. Nieto. The ins and outs of the epithelial to mesenchymal transition in health and disease. Annu. Rev. Cell Dev. Biol, 27 (2011), pp. 347-376

[97] T. Arumugam, V. Ramachandran, K.F. Fournier, H. Wang, L. Marquis, J.L. Abbruzzese, et al. Epithelial to mesenchymal transition contributes to drug resistance in pancreatic cancer. Cancer Res, 69 (2009), pp. 5820-5828

[98] D. Nantajit, D. Lin, J.J. Li. The network of epithelial-mesenchymal transition: potential new targets for tumor resistance. J. Cancer Res. Clin. Oncol (2014), 10.1007/s00432-014-1840-y

[99] E. Buck, A. Eyzaguirre, S. Barr, S. Thompson, R. Sennello, D. Young, et al. Loss of homotypic cell adhesion by epithelial-mesenchymal transition or mutation limits sensitivity to epidermal growth factor receptor inhibition. Mol. Cancer Ther, 6 (2007), pp. 532-541

[100] B.A. Frederick, B.A. Helfrich, C.D. Coldren, D. Zheng, D. Chan, P.A. Bunn, et al. Epithelial to mesenchymal transition predicts gefitinib resistance in cell lines of head and neck squamous cell carcinoma and non-small cell lung carcinoma. Mol. Cancer Ther, 6 (2007), pp. 1683-1691

[101] S. Bao, Q. Wu, R.E. McLendon, Y. Hao, Q. Shi, A.B. Hjelmeland, et al. Glioma stem cells promote radioresistance by preferential activation of the DNA damage response. Nature, 444 (2006), pp. 756-760

[102] G.Z. Cheng, J. Chan, Q. Wang, W. Zhang, C.D. Sun, L.H. Wang. Twist transcriptionally upregulates AKT2 in breast cancer cells leading to increased migration, invasion, and resistance to paclitaxel. Cancer Res, 67 (2007), pp. 1979-1987

[103] D.S. Hsu, H.Y. Lan, C.H. Huang, S.K. Tai, S.Y. Chang, T.L. Tsai, et al .Regulation of excision repair cross-complementation group 1 by Snail contributes to cisplatin resistance in head and neck cancer. Clin. Cancer Res, 16 (2010), pp. 4561-4571

[104] Latifi, K. Abubaker, N. Castrechini, A.C. Ward, C. Liongue, F. Dobill, et al. Cisplatin treatment of primary and metastatic epithelial ovarian carcinomas generates residual cells with mesenchymal stem cell-like profile. J. Cell. Biochem, 112 (2011), pp. 2850-2864

[105] Y. Shintani, A. Okimura, K. Sato, T. Nakagiri, Y. Kadota, M. Inoue, et al. Epithelial to mesenchymal transition is a determinant of sensitivity to chemoradiotherapy in non-small cell lung cancer. Ann. Thorac. Surg, 92 (2011), pp. 1794-1804

[106] S. Thomson, E. Buck, F. Petti, G. Griffin, E. Brown, N. Ramnarine, et al.E pithelial to mesenchymal transition is a determinant of sensitivity of non-small-cell lung carcinoma cell lines and xenografts to epidermal growth factor receptor inhibition. Cancer Res, 65 (2005), pp. 9455-9462

[107] R.L. Yauch, T. Januario, D.A. Eberhard, G. Cavet, W. Zhu, L. Fu, et al. Epithelial versus mesenchymal phenotype determines in vitro sensitivity and predicts clinical activity of erlotinib in lung cancer patients. Clin. Cancer Res, 11 (2005), pp. 8686-8698

[108] M. Xie, L. Zhang, C.S. He, F. Xu, J.L. Liu, Z.H. Hu, et al. Activation of Notch-1 enhances epithelial-mesenchymal transition in gefitinib-acquired resistant lung cancer cells. J. Cell. Biochem, 113 (2012), pp. 1501-1513 
[109] C. Oliveras-Ferraros, B. Corominas-Faja, S. Cufí, A. Vazquez-Martin, B. Martin-Castillo, J.M. Iglesias, et al. Epithelial-to-mesenchymal transition (EMT) confers primary resistance to trastuzumab (Herceptin). Cell Cycle, 11 (2012), pp. 4020-4032

[110] X. Li, M.T. Lewis, J. Huang, C. Gutierrez, C.K. Osborne, M.F. Wu, et al .Intrinsic resistance of tumorigenic breast cancer cells to chemotherapy. J. Natl Cancer Inst, 100 (2008), pp. 672-679

[111] S.H. Ou, L. Bazhenova, D.R. Camidge, B.J. Solomon, J. Herman, T. Kain, et al. Rapid and dramatic radiographic and clinical response to an ALK inhibitor (crizotinib, PF02341066) in an ALK translocation-positive patient with non-small cell lung cancer. J. Thorac. Oncol, 5 (2010), pp. 2044-2046

[112] T.S. Mok, Y.L. Wu, S. Thongprasert, C.H. Yang, D.T. Chu, N. Saijo, et al. Gefitinib or carboplatin-paclitaxel in pulmonary adenocarcinoma. N. Engl. J. Med, 361 (2009), pp. 947-957

[113] P.M. Comoglio, S. Giordano, L. Trusolino. Drug development of MET inhibitors: targeting oncogene addiction and expedience. Nat. Rev. Drug Discov, 7 (2008), pp. 504-516

[114] Cañadas, F. Rojo, Á. Taus, O. Arpí, M. Arumí-Uría, L. Pijuan, et al. Targeting epithelial-tomesenchymal transition with Met inhibitors reverts chemoresistance in small cell lung cancer. Clin. Cancer Res, 20 (2014), pp. 938-950

[115] X. Xiong, R.R. Arvizo, S. Saha, D.J. Robertson, S. McMeekin, R. Bhattacharya, et al. Sensitization of ovarian cancer cells to cisplatin by gold nanoparticles. Oncotarget, 5 (2014), pp. 6453-6465

[116] D. Yang, Y. Sun, L. Hu, H. Zheng, P. Ji, C.V. Pecot, et al. Integrated analyses identify a master microRNA regulatory network for the mesenchymal subtype in serous ovarian cancer. Cancer Cell, 23 (2013), pp. 186-199

[117] Y. Hüsemann, J.B. Geigl, F. Schubert, P. Musiani, M. Meyer, E. Burghart, et al. Systemic spread is an early step in breast cancer. Cancer Cell, 13 (2008), pp. 58-68

[118] E. Garralda, K. Paz, P.P. López-Casas, S. Jones, A. Katz, L.M. Kann, et al. Integrated nextgeneration sequencing and avatar mouse models for personalized cancer treatment. Clin. Cancer Res, 20 (2014), pp. 2476-2484

[119] M. Hidalgo, E. Bruckheimer, N.V. Rajeshkumar, I. Garrido-Laguna, E. De Oliveira, B. RubioViqueira, et al .A pilot clinical study of treatment guided by personalized tumor grafts in patients with advanced cancer. Mol. Cancer Ther, 10 (2011), pp. 1311-1316 